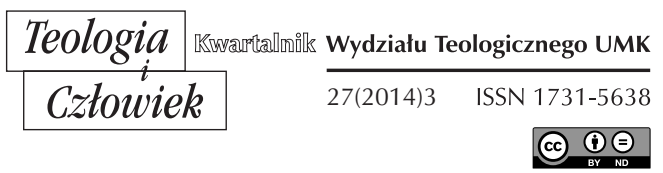

KS. MICHAŁ SADOWSKI*

WŁOCŁAWEK

\title{
MUZUŁMAŃSKA AWERSJA DO SZTUKI FIGURATYWNEJ \\ A BIZANTYJSKI IKONOKLAZM. KRÓTKA CHARAKTERYSTYKA PROBLEMU
}

DOI: http://dx.doi.org/10.12775/TiCz.2014.045

Wiele napisano na temat ikonoklazmu w Bizancjum, jego przyczyn, przebiegu, następstwach i mocodawcach. Stąd też celem niniejszego artykułu nie jest powielanie treści już prezentowanych, lecz propozycja spojrzenia na to zagadnienie $\mathrm{z}$ perspektywy wydarzeń współczesnych bizantyjskiemu ikonoklazmowi, mających miejsce $\mathrm{w}$ nowym, prężnie rozwijającym się tworze administracyjno-religijnym, jakim był kalifat Umajjadów ${ }^{1}$.

* Ks. dr Michał Sadowski jest prefektem studiów w Wyższym Seminarium Duchownym we Włocławku oraz sekretarzem czasopisma wydziałowego „Teologia i Człowiek".

${ }^{1}$ Zob.: J. Sprutta, Ikonoklazm w Bizancjum - do Soboru Nicejskiego II, "Studia Teologiczno-Historyczne Śląska Opolskiego" 24 (2004), s. 145-158; M. Chudzikowska-Wołoszyn, Początki sporów ikonoklastycznych w Bizancjum, „Studia Elbląskie” 7 (2006), s. 79-89; W. Gembalik, Ikonoklazm w islamie i jego konsekwencje w kulturze muzutmańskiej, „Nomos" 69/70 (2010), s. 39-52; O. Kashchuk, Idea pentarchii jako rękojmia jedności Kościota w dobie ikonoklazmu: stanowisko Teodora Studyty, "Vox Patrum” 58 (2012), s. 201-220; M. Jagodziński, Katolickie ujęcie teologii świętego obrazu, "Collectanea Theologia” 82 (2012), s. 57-74; M. Pус, Ikonoklazm i jego argumentacja przeciwko kultowi obrazów w ostatnim 
Można uznać, że wiedza o tego typu tendencjach zachodzących w kalifacie nie jest czymś tajemnym, ale też niekoniecznie znajduje się ona $\mathrm{w}$ zasięgu zainteresowania badaczy zagadnienia. Tajemnicą poliszynela jest fakt wzajemnych oddziaływań zachodzących między Bizancjum a nowo powstałym kalifatem. Oddziaływania te niekoniecznie należy redukować wyłącznie do starć militarnych, ale warto na nie spojrzeć w szerszym kontekście przemian zachodzących we wspomnianym państwie muzułmańskim, które niejednokrotnie miały charakter kalki tego, co dokonywało się za jego północno-zachodnią granicą.

Biorąc pod uwagę chronologię, można zapytać, czy bizantyjski ikonoklazm może mieć podstawy $\mathrm{w}$ islamskiej teologii oraz rozporządzeniach administracyjnych poszczególnych kalifów.

\section{CHRONOLOGIA}

O ewentualnym muzułmańskim wpływie na wydarzenia $\mathrm{w}$ Bizancjum dowiadujemy się z akt Soboru Nicejskiego (787 r.). Sobór, który zebrał się, aby potępić walczących przeciw obrazom oraz wesprzeć ich doktrynalnych przeciwników, podaje interesującą informację dotyczącą genezy ruchu ikonoklastycznego w Imperium Bizantyjskim. Stwierdza bowiem, że cesarz Leon III (717-741) wprowadził w roku 726 doktrynę ikonoklazmu do Bizancjum, wzorując się na poczynaniach umajjadzkiego kalifa Jazida II ibn Abd al-Malika (720-724)2 . Wspomniane przedsięwzięcie Jazida to największa, choć nie jedyna, akcja skierowana przeciwko chrześcijańskim ikonom i krzyżom znajdującym się w przestrzeni publicznej, włączając kościoły, podjęta w roku 721. Ktokolwiek szukałby edyktu w wersji oryginalnego dokumentu, dozna zawodu, gdyż o jego istnieniu dowiadujemy się wyłącznie z kronik greckich, syryjskich, ormiańskich czy arabskich ${ }^{3}$.

z chrystologicznych sporów chrześcijańskiej starożytności, "Colloquia Theologica Ottoniana" 1 (2012), s. 23-35; M. Wąchocka, Łaska w ikonach, „Polonia Sacra” 17 (2013), s. 203-218.

${ }^{2}$ Zob. J. D. Mansi, Sacrorum Conciliorum Nova, et Amplissima Collectio, Florence 1757, t. XIII, kol. 197, 200 (grecki), kol. 198-199 (łacina).

${ }^{3}$ Zob. A. A. Vasiliev, The Iconoclastic Edict of the Caliph Yazid II A.D. 721, „Dumbarton Oak Papers” 9/10 (1956), s. 27nn. 


\section{1. ŹRÓDŁA GRECKIE}

Pierwszeństwo źródeł greckich w tym zestawieniu jest ściśle związane z chronologią. To właśnie w tekście greckim, a dokładniej w liście autorstwa Germana, patriarchy Konstantynopola (715-730), do jednego z ikonoklastycznych biskupów Azji Mniejszej, Tomasza z Klaudiopolis, po raz pierwszy napotykamy zapis mówiący raczej o muzułmańskich przesądach dotyczących idolatrii aniżeli dostarczający jakichkolwiek informacji o islamskim ikonoklazmie. List ten powstał około roku 724 i jest zachowany w aktach wspomnianego Soboru Nicejskiego (787 r. $)^{4}$. Autor listu wskazuje na Żydów jako tych, którzy zarzucają chrześcijanom idolatrię w formie kultu obrazów, nazywając ich samych „prawdziwymi

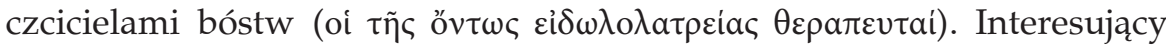

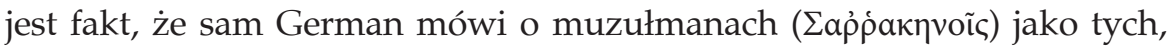
którzy czynią coś podobnego, ponieważ czczą na pustyni nieożywiony kamień $(\lambda i \theta \omega$ ả $\psi v \dot{x} \omega)$, nazywany Chobar (Xoßà $\rho)^{5}$. Mimo że w liście patriarchy nie znajdujemy wzmianki o edykcie Jazida, wskazuje on, że jego autor uważał Żydów i muzułmanów za prawdziwych bałwochwalców. A. A. Vasiliev zauważa, że wbrew ikonoklastycznej polityce cesarza Leona III, do lat 30. VIII wieku jego polityka nie była raczej burzliwa ani nietolerancyjna, skoro głową bizantyjskiego Kościoła była osoba wprost sprzeciwiająca się $\mathrm{mu}^{6}$. Inni uczeni, jak G. Ostrogorski i G. B. Ladner, utrzymywali, że Leon, zanim powziął dalsze, bardziej drastyczne kroki, starał się drogą pokojową nawrócić swych poddanych ${ }^{7}$.

Za najważniejsze źródło w kontekście genezy ikonoklazmu z punktu widzenia kronikarzy greckich należy uznać raport Jana z Jerozolimy, który w jednym ze swoich tekstów odniósł się do wpływów muzułmańskich oraz żydowskich. Dokument ten został odczytany na piątej sesji Soboru Nicejskiego (4 października 787 roku). Ze względu na ograniczoną dostępność wspomnianych źródeł poniżej zostanie przytoczone tłumaczenie wersji angielskiej tekstu greckiego.

${ }^{4}$ Zob. J. D. Mansi, dz. cyt., kol. 109D-E.

${ }^{5}$ Podobną uwagę można dostrzec u Jana z Damaszku, który interpretuje

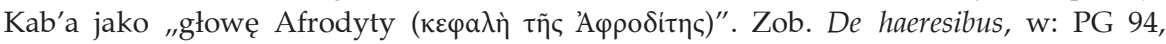
kol. 768D-769B.

${ }^{6}$ Zob. A. A. Vasiliev, dz. cyt., s. 27nn.

7 Zob. G. Ostrogsky, Les débuts de la querelle des images, „Mélanges Charles Diehl", Paryż 1930, t. I, s. 238-242; zob. G. B. Ladner, Origin and Significance of the Byzantine Iconoclastic Controversy, „Mediaeval Studies”, vol. II, New York-London 1940, s. 135. 
Wspomniawszy śmierć kalifa Sulejmana ( $\sigma \dot{\mu} \mu ß o u \lambda o \varsigma, \Sigma \varepsilon \lambda \varepsilon \mu \alpha \dot{v} v)$, Jan z Jerozolimy kontynuował:

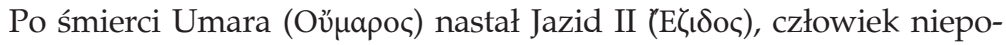
ważny i niezrównoważony. Żył w Tyberiadzie pewien przywódca awanturniczych Żydów, czarownik i wróżbiarz oraz narzędzie niszczących duszę demonów, imieniem Tessarakontapechys ${ }^{8}[. .$.$] . Zdobywszy wiedzę$ o braku powagi władcy Jazida, zbliżył się do niego i zaczął wypowiadać proroctwa [...] mówiąc: „Będziesz żył długo i rządził przez trzydzieści lat, jeśli posłuchasz mojej rady [...] Wydaj natychmiast, bez żadnej zwłoki

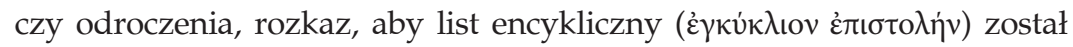
posłany na całe twe imperium po to, żeby każde figuratywne malowidło

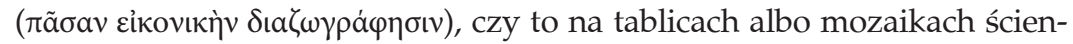
nych lub też świętych naczyniach i obrusach ołtarzowych; wszystkie takie obiekty [które] znajdują się we wszystkich kościołach chrześcijańskich, powinny być zniszczone i w końcu zakazane. A więc także wszelkie wizerunki czegokolwiek, zdobiące i upiększające targowe miejsca miast [...]". Ten bezbożny tyran, uległszy jego namowie, posłał [swych] przedstawicieli i najbardziej lekkomyślnie zniszczyli święte ikony i wszystkie inne wizerunki w całej prowincji, nad którą sprawował władzę, a dzięki żydowskiemu czarownikowi, bezlitośnie okradli kościoły Boże, pod jego wpływem, ze wszystkich ornamentów, zanim zło przyszło do tego kraju. Jako że chrześcijanie uciekli, żeby oni sami nie musieli niszczyć świętych obrazów własnymi rękoma, wysłani w tym celu emirowie, zmusili do tego zadania wstrętnych Żydów i przeklętych Arabów, i tak spalili oni czcigodne ikony, brudząc albo też skrobiąc budynki kościelne.

Słysząc o tym, pseudobiskup Nakolii oraz jego zwolennicy szli za awanturniczymi Żydami i bezbożnymi Arabami i znieważyli kościoły

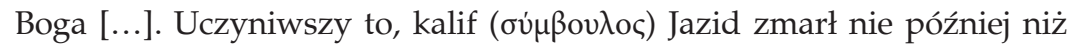
dwa i pół roku po tym, a obrazy zostały przywrócone do ich nieskazitel-

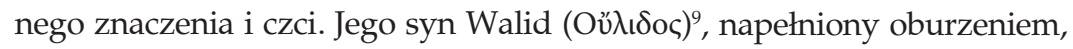
rozkazał sromotnie przyprawić czarownika o bratobójczą śmierć, jako właściwą nagrodę za jego fałszywe proroctwo ${ }^{10}$.

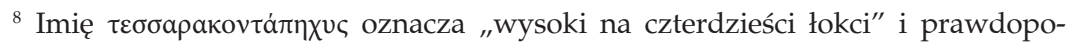
dobnie może być identyfikowane z pewnym człowiekiem zatrudnionym przez cesarza Leona, o którym wspomina anonimowa arabska kronika zatytułowana Kitāb al-'Uyūn, gdy używa ona pseudonimu "Czterdziestołokciowy". Więcej na temat tego imienia zob.: A. A. Vasiliev, dz. cyt., s. 28, przypis 12 .

${ }^{9}$ Chodzi zapewne o kalifa Hiszama ibn al-Malika (724-743), po którym panował Walid III (743-744).

${ }^{10}$ Tekst grecki: J. D. Mansi, dz. cyt., kol. 197-199; tekst angielski: K. A. C. Creswell, The Lawfulness of Painting in Early Islam, "Ars Islamica” 11/12 (1946), s. 164. 
Nawet pobieżna lektura powyższego tekstu zdaje się sugerować, że rozporządzenie Jazida nie miało żadnych podstaw w ówczesnym islamie, co więcej - zostało ono szybko odwołane przez jego następcę. Nasuwa się więc pytanie, czy są podstawy, by walkę z obrazami w kalifacie za rządów Jazida przypisać słabościom jego charakteru będącego pod wpływem żydowskiego lidera? Wskazując na żydowski ślad, H. Lammens powołuje się na hadis inspirowany właśnie żydowskimi wpływami, w którym czytamy: „Aniołowie nie wejdą do domu, w którym jest dzwon, obraz lub pies”, a także: „przy końcu świata, kiedy 'Isā objawi się, połamie on krzyże i powybija świnie"11. Skąd wiadomo, że to arabskie powiedzenie ma żydowskie źródła? Ewidentnym dowodem na to jest mowa o dzwonach, których współcześni Mahometowi Arabowie po prostu nie znali, oraz świniach, które we wczesnym islamie nie budziły jeszcze odrazy ${ }^{12}$. Można zatem mówić tutaj o konkretnych wpływach literatury talmudycznej ${ }^{13}$. Dość niezwykłe wydaje się, że walka z chrześcijańską sztuką figuratywną w kalifacie Umajjadów ma swój początek we wpływach żydowskich, a nie była ona efektem zorganizowanego ruchu ikonoklastycznego na terenie Bizancjum. Mało prawdopodobne jest także to, że był on rezultatem spontanicznego działania wspólnoty muzułmańskiej. Warto wspomnieć, że żydowskie wpływy w kalifacie były umacniane przez żydowskich konwertytów na islam, cieszących się ogólnym uznaniem i pełniących ważne społeczne funkcje ${ }^{14}$.

Kolejną relację mówiącą o tym, co działo się poza granicami Bi-

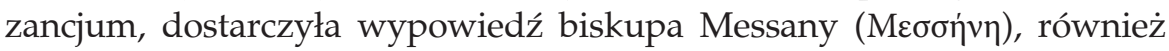
obecnego na Soborze Nicejskim, który wspominając swe dzieciństwo spędzone w Syrii, przywołał kalifa saraceńskiego niszczącego ikony ${ }^{15}$. Z kolei

${ }^{11} \mathrm{H}$. Lammens, L'Attitude de l'Islam primitif en face des arts figurés, "Journal asiatique" IIme série, 6 (1915), s. 276-277.

${ }^{12}$ Na temat świń Koran wypowiada się w następujących surach: 2,173; 5,3; 5,60; 6,$145 ; 16,114$. O restrykcjach związanych z mięsem wieprzowym zob. R. Lobban, Pigs and their Prohibition, "International Journal of the Middle East Studies” 26 (1994), s. 57-75.

${ }^{13}$ Zob. H. Lammens, dz. cyt., s. 276-277.

${ }^{14}$ Warto tu wspomnieć jemeńskiego Żyda Ka‘b al-Aḥbāra (†652/654), człowieka wielkiej wiedzy teologicznej i biblijnej, uważanego za autorytet $\mathrm{w}$ dziedzinie hadisów, czy też Wahba ibn Munabbiha (ur. ok. 654). Zob.: M. Schmitz, Ka'b al-Aḥbār, w: E. Van Donzel et all. (red.), The Encyclopaedia of Islam, vol. IV, Leiden 1997, s. 316-317; R. G. Khoury, Wahb b. Minabbih, w: P. J. Bearman et all. (red.), The Encyclopaedia of Islam, vol. XI, Leiden 2002, s. 34-36.

15 Zob. J. D. Mansi, dz. cyt., kol. 200. 
Teofanes, piszący swą kronikę w IX wieku, przyznał, że Jazid wydał swój ikonoklastyczny edykt za namową pewnego żydowskiego czarownika z Laodycei, obiecującego mu czterdziestoletnie panowanie ${ }^{16}$. Patriarcha Konstantynopola Nicefor I (805-816) w dziele Antirrhetici (Kontrargumenty) adresowanym do najbardziej zaciekłych zwolenników ikonoklazmu (na czele z cesarzem Konstantynem V Kopronimem) zamieścił wzmiankę

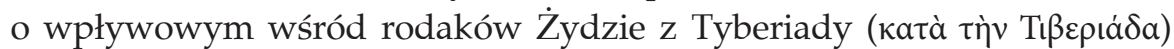

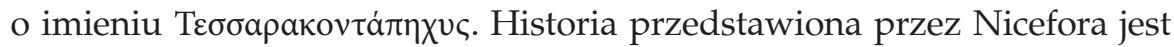
podobna do tej, o której mówił Jan z Jerozolimy. Nicefor zauważa także, że zło ikonoklazmu rozlało się w efekcie na całe Cesarstwo Rzymskie ${ }^{17}$. O żydowskiej odpowiedzialności za niszczenie ikon w kalifacie pisał także żyjący w IX wieku Grzegorz Hamartolos ${ }^{18}$.

\section{2. ŹRÓDŁA SYRYJSKIE I ARABSKIE}

Obok greckich źródeł, należy przeanalizować także źródła syryjskie i arabskie. Pochodząca z IX wieku tzw. Kronika Pseudo-Dionizego podaje, że w roku 1035 ery Seleucydów (ok. 723-724) Jazid rozkazał usunąć wszelkie obrazy gdziekolwiek się one znajdowały, zarówno w kościołach, jak i w domach prywatnych ${ }^{19}$. Spisana w XII wieku kronika patriarchy Syryjskiego Kościoła Prawosławnego Michała Syryjczyka (1166-1199) dwukrotnie przywołuje omawiane wydarzenia. Dowiadujemy się z niej, że Jazid - król Arabów (Taiyayê) - rozkazał zburzyć i rozbić na kawałki znajdujące się w świątyniach, na budynkach, ścianach, belkach i skałach malowidła oraz posągi przedstawiające wszystko, co żyje i się porusza. Nie oszczędzano także ksiąg, drąc te, które były zdobione obrazkami. Dopełnieniem tej informacji jest wzmianka o decyzji walki z obrazami podjętej przez cesarza Bizancjum Leona III, inspirowanego działaniem króla Arabów, który zalecił niszczenie wszelkich malowideł, zarówno tych przedstawiających świętych, jak i cesarzy ${ }^{20}$. Ostatnim świadectwem s. $401-402$.

${ }^{16}$ Zob. Theophanes Continuatus, Chronographia, I. Bekker (red.), Bonn 1838,

17 Zob. Nicefor, Antirrheticus, PG 100, III, kol. 528-534.

18 Zob. Grzegorz Hamartolos, Chronikon, C. de Boor (red.), Lipsiae 1904, s. $735-736$.

${ }_{19}$ Zob. Chronique de Denys de Tell-Mahré, J. B. Chabot (red. i tłum.), Paris 1895, s. $17-18$.

${ }^{20}$ Zob. Chronique de Michel le Syrien, J. B. Chabot (red. i tłum.), Paris 1901, 
syryjskim, które można tutaj przywołać, jest anonimowa kronika spisująca dzieje świata do roku 1234. W odróżnieniu od poprzednich tekstów podaje ona pewien szczegół dotyczący omawianych wydarzeń. Jej autor notuje, że w 102 roku Hidżry (720/721) niejaki Maslamas, na mocy rozporządzenia swego brata Jazida, był odpowiedzialny za wykonanie rozkazu niszczenia obrazów ${ }^{21}$.

Wśród źródeł arabskich możemy znaleźć wzmiankę o przedsięwzięciu Jazida u żyjącego w IX wieku arabskiego historyka Abū ‘Umara Muḥammada al-Kindiego (897-961)22 oraz u Taqiego al-Dīna Aḥmada al-Maqrīziego (1364-1442). Ten drugi, poświadczając to, o czym już wiadomo z wyżej prezentowanych źródeł, wspomina także o decyzji następcy Jazida, Hiszama, który pozwolił egipskim chrześcijanom na powrót do ich religijnych zwyczajów ${ }^{23}$.

Oprócz tych kilku historyków muzułmańskich, piszących rzecz jasna po arabsku, nie wolno pominąć żyjącego w Egipcie koptyjskiego historyka Sāwīrusa ibn al-Muqaffa' (910-987), autora wielkiego dzieła - Historia Patriarchatu Aleksandrii od św. Marka do Michała I24. Chociaż w jego historii próżno szukać wzmianki o edykcie Jazida, to można tam znaleźć informacje przedstawiające życie religijne egipskich chrześcijan, ich cierpienie i prześladowanie pod muzułmańskimi rządami przed walczącym z obrazami kalifem. Sāwīrus nawiązuje do praktyk

vol. II, XI, 19, s. 488-491 (tekst francuski). Zob. także Gregorius Bar-Hebraeus, The Chronography, E. A. W. Budge (tłum.), London 1932, s. 109.

${ }^{21}$ Zob. Chronicon Anonymum ad annum Christi 1234 pertinens, J. B. Chabot (red. i tłum.), CSCO Scriptores Syrii 3, Louvain 1937, s. 240.

${ }^{22}$ Zob. F. Rosenthal, Al-Kindī, Abū 'Umar Muhammad, w: C. E. Bosworth et all. (red.), The Encyclopaedia of Islam, vol. V, Leiden 1986, s. 121-122. Zob. także A. A. Vasiliev, dz. cyt., s. 39, przypis 45 (Vasiliev podaje błędne strony dzieła al-Kindiego).

${ }^{23}$ Zob. F. Rosenthal, Al-Maqrīzī, Taqī al-Dīn, w: C. E. Bosworth et all. (red.), The Encyclopaedia of Islam, vol. VI, Leiden 1991, s. 193-194. Zob także A. A. Vasiliev, dz. cyt., s. 39.

${ }^{24}$ Zob. G. Graf, Geschichte der christlichen arabischen Literatur, vol. II, Città del Vaticano 1947, s. 300-306. Edycje tego dzieła: Sawirus ibn al-Mukaffa' (Muqaffa), History of the Patriarchs of the Egyptian Church, vol. I, cz. 1, B. Evetts (red. i tlum.), Paris 1904; vol. I, cz. 2, w: Patrologia Orientalis 1, cz. 2, Paris 1907; vol. I, cz. 3, Patrologia Orientalis 5, Paris 1910; C. F. Seybold (red.), Severus ibn al-Muqaffa', Alexandrinische Patriarchengeschichte von S. Marcus bis Michael I (61-767), nach der ältesten 1266 geschriebenen Hamburger Handschrift im arabi-schen Urtextherausgegeben, Hamburg 1912; tenże, Severus Ben el-Moqaffa', Historia Patriarcharum Alexandrinorum, CSCO 52, 59, Scriptores Arabici 8, 9, ser. 3. 
kalifa 'Abd al-Malika (685-705), który „zarządził niszczenie wszystkich krzyży, jakie były w Egipcie, również tych ze srebra i złota. Co więcej notuje historyk - wykonał on pewne inskrypcje i umieścił na drzwiach kościołów w Miṣr i w Delcie, mówiąc w nich: «Mahomet jest wielkim apostołem Boga i Jezus także jest apostołem Boga. Lecz zaprawdę Bóg nie jest zrodzony ani nie zrodził»"25. Sāwīrus wspomina także rok 705 i zarządcę Egiptu 'Abd al-'Aziza oraz jego syna, al-Asbagha, krwawego prześladowcę chrześcijan, który bezczeszcząc ikonę Matki Bożej w jednym z monasterów, zapowiedział eksterminację egipskich chrześcijan ${ }^{26}$. Następnie historyk przytacza rok 714, w którym nakazano pozbawić kościoły wszelkich kolorowych kolumn, oraz rok 718, w którym to za panowania kalifa Umara II (717-720) chrześcijanie mogli początkowo czuć się bezpiecznie, a kościoły i biskupi byli wyjęci spod obowiązku płacenia podatków. Jednak na mocy pewnego rozporządzenia władcy każdy, kto zamieszkiwał te tereny, był zobowiązany do przejścia na religię Mahometa pod groźbą wygnania. Ponadto, jak wspomina Sāwīrus, na tych, którzy nie zostali muzułmanami, nałożono podatki ${ }^{27}$. Jeśli chodzi o samego Jazida, to Sāwīrus jest powściągliwy i nie chce opisywać tego wszystkiego, co działo się za jego panowania. Wspomina tylko, że szedł on (Jazid) drogą szatana, przywracając podatki i doprowadzając ludzi do rozpaczy. Niszczył święte wizerunki i krzyże i umarł wkrótce $\mathrm{w}$ wielkich męczarniach ${ }^{28}$.

\section{PRÓBA DIAGNOZY PRZYCZYN}

Opierając się na przytoczonych tekstach źródłowych, raczej trudno doszukać się $\mathrm{w}$ nich informacji pomocnej w odpowiedzi na pytanie o przyczyny walki z krzyżami i obrazami za rządów niektórych kalifów umajjadzkich. Owszem, wątek żydowski jest ważny, lecz chyba niekoniecznie wystarczający do wytłumaczenia tego zjawiska.

${ }^{25}$ Zob. B. Evetts, History of the Patriarchs of the Coptic Church of Alexandria, Patrologia Orientalis 5, s. 25. Ostatnie zdanie nawiązujące do inskrypcji jest wyraźną aluzją do koranicznej sury 112, 3 .

${ }^{26}$ Zob. tamże, s. 52-54.

27 Zob. tamże, s. 71-72.

${ }^{28}$ Zob. tamże, s. 72-73. 


\subsection{NAMACALNOŚĆ NOWEGO STATUS QUO}

Muzułmańska konkwista Bliskiego Wschodu, mimo że stała się niezaprzeczalnym faktem $\mathrm{w}$ kontekście geografii, na różne sposoby ustępowała ciągle miejsca pozostałościom poprzedniego porządku. Były one ważne, ponieważ obnażały słabość nowego tworu administracyjno-religijnego. Stąd też zaistniała konieczność rozliczenia się z przedislamską przeszłością. Przytoczone powyżej źródła wspominają o niszczeniu krzyży znajdujących się $\mathrm{w}$ przestrzeni publicznej oraz prywatnej. Warto zauważyć, że praktyka ta towarzyszyła najazdom muzułmańskim na osady chrześcijańskie od samego początku. Syryjscy kronikarze notują, że za czasów kalifa 'Umara (634-644) ${ }^{29}$ oraz jego następcy Uthmāna (644-656) krzyże były obalane, ściągane ze ścian oraz obowiązywał zakaz ich pokazywania w dni świąteczne i Dni Krzyżowe (Dni błagalne) ${ }^{30}$.

Walka z krzyżem to początek przemian prowadzących do wyraźnego ukazania hegemonii islamu i kalifatu na podbitych terenach. I tak, dowiadujemy się, że rządca Egiptu 'Abd al-'Azīza ibn Marwān (zm. 705) jest autorem przeprowadzonej $\mathrm{w}$ latach 676-689 reformy mającej raczej pobudki polityczne aniżeli wyłącznie teologiczne, podsycane niechęcią do sztuki figuratywnej. Skąd taka uwaga? Krzyż był najbardziej rozpowszechnionym motywem religijnym wśród wszystkich denominacji chrześcijan Bliskiego Wschodu i przetrwał nawet w najbardziej surowych koncepcjach wystroju świątyń ${ }^{31}$. Z jednej strony, krzyż stanowił dla chrześcijan (także ikonoklastów) znak Chrystusa oraz przedmiot czci i szacunku, uważali oni, że chronił ich przed złem, przypisywali mu moc cudotwórczą. Z drugiej, był on symbolem Cesarstwa Bizantyjskiego, szczególnie od czasów Herakliusza (610-641), za którego panowania odnaleziono Święty Krzyż zrabowany przez Persów, wybijając jego motyw na monetach ${ }^{32}$. Polityka kalifów przełomu wieków, 'Abd al-Malika ibn Marwāna (685-705) i jego syna al-Walīda ibn Abd al-Malika (705-715), mając pokrycie $\mathrm{w}$ zdobyczach terytorialnych oraz pojawiając się jako

29 Szereg zasad, zakazów i nakazów, jakie miały obowiązywać niemuzułmanów, zawarty jest w tzw. Umowie 'Umara. Zob. A. S. Tritton, The Caliphs and their non-Muslim Subjects; a Critical Study of the Covenant od 'Umar, London 1930, s. 5-8.

${ }^{30}$ Zob. Chronicon Anonymum ad annum Christi 1234 pertinens, s. 262.

31 Zob. G. R. D. King, Islam, Iconoclasm, and the Declaration of Doctrine, "Bulletin of the School of Oriental and African Studies" 48 (1985), s. 272.

${ }^{32}$ Zob. tamże, s. 273. 
bardziej wyrazista obecność arabskiego i islamskiego charakteru państwa w sferze publicznej, zaprowadziła dynastię Umajjadów na szczyty potęgi. By to osiągnąć, realizowano $\mathrm{z}$ rozmachem projekty budowlane na miarę "Justyniana, Hadriana i Heroda"33. Do efektów tych działań można zaliczyć budowę meczetu Kopuła na Skale (Qubbat al-Sakhrah) w Jerozolimie oraz Meczetu Umajjadów (Jāmi' Banī Umayya al-Kabīr), wzniesionego na miejscu kościoła św. Jana Chrzciciela w Damaszku. Jego budowniczowie nie tyle zniszczyli kościół, ile obudowali go meczetem, obrazując tym samym panowanie islamu nad chrześcijaństwem ${ }^{34}$. Drugim etapem wzmacniania obecności islamu i kalifatu w przestrzeni publicznej była reforma systemu monetarnego, w wyniku której bito własne monety pozbawione symboliki chrześcijańsko-bizantyjskiej. Symbolika ta została zastąpiona motywami własnymi, takimi jak arabskie inskrypcje zaczerpnięte z Koranu czy też inne obwieszczające władzę kalifa ${ }^{35}$. Warto zauważyć, że reforma monetarna zapoczątkowana przez kalifa 'Abd al-Malika ibn Marwāna mogła być swoistą odpowiedzią na podobny krok, którego inicjatorem w Bizancjum był cesarz Justynian II (685-695, 705-711) i którego wizualnym efektem była podobizna Chrystusa i motyw krzyża widniejące na tamtejszych monetach ${ }^{36}$. Oprócz wymiaru czysto politycznego zauważalny jest tu także wydźwięk teologiczny - umieszczane na arabskich monetach inskrypcje nawiązywały bowiem do głównych treści spornych między islamem a chrześcijaństwem w zakresie nauki o jedności Boga, czy roli Chrystusa.

\subsection{KWESTIE SPORNE}

Dominacja islamu nie mogła być ograniczona do żadnej ze sfer życia publicznego mieszkańców kalifatu. Oprócz monet i monumen-

${ }^{33}$ Zob. S. Griffith, Images, Islam and Christian Icons. A Moment in the Christian/ Muslim Encounter in Early Islamic Times, w: P. Canivet, J.-P. Rey-Coquais (red.), La Syrie de Byzance a l'islam VII -VIII siècles. Actes du Colloque International Lyon-Maison de l'Orient Mèditerranéen 11-15 septembre 1990, Paris 1992, s. 123.

${ }^{34}$ Zob. tamże, s. 124.

${ }^{35}$ Informację o nowych monetach znajdujemy w Kronice Michała Syryjczyka, który notuje, że w roku 1008 (697 A.D.) Arabowie zaczęli bić dināry, zūzę i obole, na których w ogóle nie było wizerunków, lecz same napisy. Chronique de Michel le Syrien, s. 473.

${ }^{36}$ Zob. J. D. Breckenridge, The numismatic iconography of Justinian II (685-695, 705-711 A.D.), New York 1959, s. 76-77. 
talnej zabudowy musiała dokonać się także na płaszczyźnie religijnej, a areną tego typu działań stała się religijna przestrzeń architektoniczna czy sakralna. Z zapisków wspomnianego już koptyjskiego historyka Sāwīrusa ibn al-Muqaffa' dowiadujemy się, że władze kalifatu walczyły z chrześcijaństwem również słowem pisanym, słowem objawionym. Mowa tutaj o doktrynalnej polemice prowadzonej za pomocą koranicznych inskrypcji ${ }^{37}$. Cytaty mówiące o równości Mahometa i Jezusa jako Bożych proroków czy wyrażające jedność i jedyność Boga w ujęciu koranicznym były niczym innym jak zaprzeczeniem tego, co chrześcijańskie w przestrzeni publicznej oraz świątynnej. Warto przy okazji wspomnieć wybudowany w 691 roku w Jerozolimie meczet Kopuła na Skale, którego sam wystrój manifestuje zwycięstwo islamu oraz przedstawia tę religię jako sukcesora dwóch dotychczasowych wyznań monoteistycznych ${ }^{38}$. Umieszczone $\mathrm{w}$ nim inskrypcje bezpośrednio nawiązują do tych artykułów doktryny chrześcijańskiej, które są niezgodne z nauką islamu. Napisy te funkcjonują ikonograficznie na tej samej zasadzie co obrazy i ikony w tego typu budowlach chrześcijańskich. Cytowane sury odnoszą się do Bożego błogosławieństwa, aniołów oraz proroka Mahometa, mówią o jedności Boga niemającego równego sobie towarzystwa (syna). Wyznawcom islamu dane jest ostrzeżenie, aby nie opuszczali zasad swej religii, przy jednoczesnym przypomnieniu, że Mesjasz-Jezus jest wyłącznie synem Marii, Boskim posłańcem, a Boska jedność jest wyraźnie wyartykułowana, podczas gdy wiara w Trójjedynego Boga zdecydowanie odrzucona ${ }^{39}$. Utrzymane $\mathrm{w}$ takim duchu inskrypcje tworzą specyficzny klimat teologiczny, ucząc czegoś całkowicie przeciwnego w stosunku do tego, co było wyrazem chrześcijańskich krzyży, ikon czy fresków. Ponadto aikoniczne motywy przedstawiające winorośle, drzewa, liście, owoce, zdobiące Meczet Umajjadów czy Kopułę na Skale, wytyczały kierunek rozwoju muzułmańskiej architektury sakralnej ${ }^{40}$. Mówiąc o przestrzeni publicznej i języku, warto pamiętać, że w tym czasie także drogowskazy były pisane $w$ języku arabskim, a przy drogach, jak i innych eks-

37 Zob. G. R. D. King, dz. cyt., s. 274.

38 Zob. O. Garbar, The Ummayad Dome of the Rock, "Ars Orientalis" 3 (1959), s. 54; zob. G. R. D. King, dz. cyt., s. 274.

${ }^{39}$ Moża tu wyróżnić takie teksty, jak: sura 4, werset 157; sura 5, wersety: 17, 72-75, 116.

${ }^{40}$ Zob. S. Griffith, dz. cyt., s. 124. Prezentacja i tłumaczenie inskrypcji znajdujących się w meczecie Kopuła na Skale zob. http://www.islamic-awarness.org/History/ Islam/Inscriptions/DoTR.html (dostęp 24.09.2014). 
ponowanych miejscach, umieszczano tekst muzułmańskiego wyznania wiary, szahady ${ }^{41}$.

\subsection{RACJE TEOLOGICZNE}

Przedstawione powyżej fakty dotyczyły pewnych wydarzeń historycznych, będących rezultatem polityki umacniania pozycji religii i władzy w społeczeństwie chrześcijańsko-muzułmańskim. Jednak należy pamiętać, że względy polityczne nie były jedynymi pobudkami, którymi kierowali się poszczególni władcy muzułmańscy. Dla muzułmanina absolutną normą regulującą życie prywatne oraz publiczne, religijne i polityczne jest Koran. Stąd też warto zwrócić uwagę na pewne jego fragmenty, które mogły posłużyć za ideologiczny katalizator decyzji o charakterze politycznym.

Tym, co na pierwszy rzut oka razi muzułmanina w spotkaniu z chrześcijaństwem, jest krzyż. Koran odrzuca chrystologię chrześcijańską z Jezusową śmiercią i ofiarą na krzyżu. Islam idzie tutaj ścieżką doketystów, uznając ukrzyżowanie za "przewidzenie”, a naukę o nim za poważny błąd. Wyrazem takiej teologii jest sura 4, werset 157, w której czytamy:

I za to, że powiedzieli: „zabiliśmy Mesjasza, Jezusa, syna Marii, posłańca Boga" - podczas gdy oni ani Go nie zabili, ani Go nie ukrzyżowali, tylko im się tak zdawało; i, zaprawdę, ci, którzy się różnią $\mathrm{w}$ tej sprawie, są z pewnością $\mathrm{w}$ zwątpieniu; oni nie mają o tym żadnej wiedzy, idą tylko za przypuszczeniem; oni Go nie zabili z pewnością.

Tekst zwraca uwagę na następujące wyrażenia: Jezus jest wyraźnie uważany za posłańca Boga (rasūl Allāh), który nie został zabity ( $m \bar{a}$ qataluwhu) ani też nie zginął śmiercią krzyżową (wa lā șalabūhu). To, co z punktu widzenia chrześcijan miało miejsce na krzyżu, jest uważane za przewidzenie (shubbiha lahum), które nie ma poparcia w faktach. Dalej sura 5 werset 17 jasno stwierdza, że ci, którzy uznają Mesjasza za Boga, nie uwierzyli temu Bogu ${ }^{42}$. Podobny ton ma sura $5 \mathrm{w}$ wersecie 72 . Tutaj Koran

${ }^{41}$ Zob. M. Sharon, An Arabic Inscription from the Time of the Caliph 'Abd al-Malik, „Bulletin of the School of Oriental and African Studies” 29 (1966), s. 367-372.

42 „Nie uwierzyli ci, którzy powiedzieli: «Zaprawdę, Bogiem jest Mesjasz, syn Marii!» Powiedz: «Któż ma możność uczynić coś przeciw Bogu, jeśli On zechce zgubić 
wkłada w usta Jezusa słowa, które przeczą Jego bóstwu: „Oto, zaprawdę, kto daje Bogu współtowarzyszy (yushrika bi-Allah), temu Bóg zabronił wejścia do Ogrodu!", co jest wyraźną aluzją nie tylko do chrześcijańskiej chrystologii oraz nauki o Trójcy Świętej i oskarżenia chrześcijan o idolatrię, czyli przypisywanie Bogu towarzyszy. Bezpośrednio do dogmatu o Trójjedynym Bogu nawiązuje następny werset tej samej sury, w którym czytamy, że nie uwierzyli ci, którzy powiedzieli: „Bóg to trzeci z trzech (Allāha thālithu thalathatin)". Po raz kolejny chrześcijanie zostają sklasyfikowani jako niewierni $(k a f f a ̈ r)^{43}$. Na zakończenie tej serii chrystologicznych wersetów sury 5 ostatni z nich domyka klamrę zaprzeczeń doktrynalnych adresowanych do chrześcijan, powtarzając, że Mesjasz jest tylko posłańcem (mā al-Masīh illà rasūlu), tak jak ci, którzy byli i przeminęli przed nim (qadu khalatu min qblihi al-rusulu). W rezultacie takich błędów muzułmanie jawią się jako ci, którzy przynoszą prawdę i wyjaśniają znaki. Znamiennym w tym kontekście tekstem jest werset 116 tejże sury, który ujawnia stan wiedzy muzułmanów na temat doktryny wiary chrześcijan ${ }^{44}$.

Oprócz krzyża, który w świetle powyższych tekstów jest nieporozumieniem, nie może być mowy także o jakimkolwiek Bożym Synu. $\mathrm{W}$ tym miejscu warto przypomnieć sobie przesłanie napisów umieszczanych na kościołach. W ich świetle Jezus był prorokiem, takim jak Mahomet, gdyż Bóg nie może być ojcem ani też mieć syna. Jest to wyraźna aluzja do sury 112, która w swych czterech wersach wyraża całość islamskiego rozumienia Boga ${ }^{45}$. Chrześcijańska nauka krzyża stanowiła zatem klin wbity między słowem objawionym, jakim jest dla muzułmanów Koran, a jego adresatami, którzy słowo to przyjęli i pragnęli według niego żyć.

Mesjasza, syna Marii, jak również Jego Matkę i wszystkich, którzy są na ziemi?» Do Boga należy królestwo niebios i ziemi, i tego, co jest między nimi. On stwarza to, co chce. Bóg jest nad każdą rzeczą wszechwładny!"

${ }^{43}$ Zob. S 5,73.

44 „I oto powiedział Bóg: «O Jezusie, synu Marii! Czy ty powiedziałeś ludziom: Bierzcie mnie i moją matkę za dwa bóstwa, poza Bogiem?» On powiedział: Chwała Tobie! Nie do mnie należy mówić to, do czego nie mam prawa. Jeślibym ja tak powiedział, Ty przecież wiedziałbyś o tym. Ty wiesz, co jest w mojej duszy, a ja nie wiem, co jest w Twojej. Zaprawdę, Ty dobrze znasz rzeczy ukryte!" S 5,116.

${ }^{45}$ Sura nosi arabski tytuł Al-Ikhlās (jest nazywana także największą surą), co na język polski zostało oddane jako „Szczerość Wiary”. Czytamy w niej, co następuje: „Mów: «On - Bóg Jeden, Bóg Wiekuisty! Nie zrodził i nie został zrodzony! Nikt Jemu nie jest równy!»". Zob. S 4:171; 6,100, 17,111; 23,91; 25,2. 


\section{ZAKOŃCZENIE}

Chrześcijańsko-muzułmańska literatura polemiczna, która została rozwinięta $w$ następnym stuleciu po omawianych tutaj wydarzeniach, nie porusza problemu walki z krzyżami i obrazami. Od tego czasu bowiem (tj. od początku IX wieku) wysiłki teologów chrześcijańskich skupiały się bardziej na zagadnieniach związanych z inkulturacją czy prezentacją nauki wiary ${ }^{46}$. Jest to o tyle ważne, że wskazuje, iż rozporządzenia 'Abd al-Malika czy Jazida II były nie tyle ideologiczną czy stricte teologiczną batalią przeciwko obrazom i krzyżom, ile pewnego rodzaju przedłużeniem ostrza polityki, tak nierozdzielnie złączonej $\mathrm{w}$ tym przypadku z religią. Jednak nie należy zapominać, że z muzułmańskiego punktu widzenia oddawanie czci krzyżowi jest publicznym odrzuceniem Boga, który zesłał Koran. Dlatego też muzułmańska niechęć do krzyża i obrazów upatruje w nich także pewną formę pogańskiego bałwochwalstwa, do którego nawiązuje Koran ${ }^{47}$. To przekonanie przyświecało również islamskiej kampanii za rządów Umajjadów mającej na celu usunięcie z przestrzeni publicznej bałwochwalstwa i skarcenie chrześcijan za religijne nieposłuszeństwo.

Należy wyraźnie rozgraniczyć niszczenie obrazów i krzyży w ramach obowiązującej wówczas polityki kalifatu i to, co miało miejsce w Bizancjum, gdzie toczyła się systematyczna walka o całkowite wykorzenienie sztuki figuratywnej i reprezentatywnej. Choć zarówno muzułmanie, jak i ikonoklaści twierdzili, że oddawanie czci obrazom jest tożsame $\mathrm{z}$ bałwochwalstwem potępionym $\mathrm{w}$ Biblii, to na tym zbieżność ich myślenia się wyczerpuje. Islamowi nie chodziło o teologię obrazu, jej zasadność czy też z jakichś konkretnych racji - błędność. Odrzucano obraz jako taki, jako przejaw bałwochwalstwa ${ }^{48}$.

${ }^{46}$ Zob. M. Sadowski, Chrześcijańska arabskojęzyczna literatura apologetyczna Bliskiego i Środkowego Wschodu w okresie Abbasydów (750-1050), „Studia Teologiczno-Historyczne Śląska Opolskiego" 32 (2012), s. 87-106; tenże, Teologia arabskich chrześcijan. Novum czy déjà vu?, „Teologia i Człowiek” 26 (2014). Zob. S. Griffith, dz. cyt., s. 135.

47 Zob. S 19,42 oraz 26,72-73.

${ }^{48}$ Ikonoklaści odrzucali obrazy uwielbionych postaci ludzkich. Ubóstwienie ludzi świętych, jak utrzymywali, wyciągało ich niejako z porządku dającego się zwizualizować. Ikonodule zaś przekonywali, że ubóstwienie Chrystusowego człowieczeństwa stało się dla ludzi wzorem do naśladowania, a co za tym idzie, ikony przedstawiające świętych stają się przewodnimi przykładami tych, którzy szli za przykładem Jezusa i dostąpili chwały Bożej. Piękna i znaczenia ikony należy szukać w świętości człowieka przez 
Ostatnim wartym uwagi punktem rozważań jest miejsce krzyża w ikonoklazmie. Zarówno dla bizantyjskich przeciwników obrazów, jak i orientalnych chrześcijan stroniących od obrazu krzyż nigdy nie stanowił problemu. Muzułmańskie oskarżenia o bałwochwalstwo były okazją lub przyczyną wewnątrzchrześcijańskiego spotkania w kontekście religijnych własności obrazów jako takich. W Bizancjum taka konfrontacja zaowocowała ikonoklazmem, co nigdy nie miało miejsca wśród chrześcijan zamieszkujących kalifat.

Biorąc pod uwagę powyższe stwierdzenia, nie sposób do końca zgodzić się z autorami kronik historycznych, którzy za przyczynę niszczycielskiej zawziętości stronnictwa bizantyjskich ikonoklastów dość łatwo uznawali tendencje panujące $w$ kalifacie rządzonym przez Umajjadów.

Streszczenie. Bizantyjski ikonoklazm zbiegł się w czasie z pewnymi wydarzeniami o podobnym charakterze rozgrywającymi się w kalifacie Umajjadów. Dokumenty Soboru Nicejskiego (787 r.), jak i kroniki historyczne tego okresu dopatrują się przyczyny ikonoklazmu w muzułmańskiej niechęci do sztuki figuratywnej. Celem niniejszego artykułu jest krótka charakterystyka chrześcijańskich tekstów źródłowych w kontekście przemian, jakie zachodziły na przełomie VII i VIII wieku w kalifacie Umajjadów.

Słowa kluczowe: ikonoklazm; islam; krzyż; Umajjadzi.

Summary: Muslim aversion to figurative art and the Byzantine iconoclasm. A short survey. The Byzantine iconoclasm coincided with both important and similar events that took place in the Umayyad Caliphate. The Nicaea's II (A.D. 787) conciliar documents as well as the chronicles at this time highlight the Muslim aversion to figurative art as the cause of the Byzantine iconoclasm. This paper aims to characterize Christian sources, which deal with the iconoclasm in the context of changes that took place in the Umayyad Caliphate in the turn of the $8^{\text {th }}$ and $9^{\text {th }}$ centuries.

Keywords: Iconoclasm; Islam; cross; Umayyads.

nią przedstawionego. Zob. K. Parry, Byzantine ans Melkite Iconophiles under Iconoclasm, w: Ch. Dendrinos, J. Harris, E. Harvalla-Crook i J. Herrin (red.), Porphyrogenita. Essays on the History and Literature of Byzantium and the Latn East in Honour of Julian Chrysostomides, Aldershot 2003, s. 142. 
